\title{
O processo histórico de formação do sistema-mundo capitalista e a sua dinâmica: uma interpretação baseada em Braudel, Marx, Arrighi e Wallerstein
}

\section{Henrique de Abreu Grazziotin ${ }^{1}$}

\begin{abstract}
Resumo: Este artigo tem como objetivo construir, de forma sintética, uma interpretação acerca da formação do sistema-mundo capitalista com base nos principais conceitos teóricos de Fernand Braudel, Karl Marx, Giovanni Arrighi e Immanuel Wallerstein para uma compreensão geral desse complexo fenômeno. Braudel explica a formação do capitalismo mercantil na Europa apoiado nos conceitos de vida material, economia de mercado e capitalismo, com a ascensão da sociabilidade mercantil, elemento essencial da circulação capitalista. Marx, a partir do processo de acumulação primitiva, explica como se criam as condições para a produção capitalista em que se confrontam de um lado, o capitalista, detentor dos meios de produção; e de outro, o trabalhador assalariado. Por fim, buscamos em Braudel, Arrighi e Wallerstein uma compreensão da dinâmica global do sistema-mundo no modo de produção capitalista, com sua divisão hierárquica entre centro, periferia e semiperiferia, seus ciclos sistêmicos de acumulação e suas mudanças de centro hegemônico.
\end{abstract}

Palavras-chave: Sistema-Mundo. Braudel. Marx. Arrighi. Wallerstein.

The historical process of the capitalist world-system formation and its dynamics: an interpretation based on Braudel, Marx, Arrighi and Wallerstein

\begin{abstract}
This paper aims do build, synthetically, an interpretation of the capitalist world-system's formation based on the main theoretical concepts of Fernand Braudel, Karl Marx, Giovanni Arrighi and Immanuel Wallerstein, for a general comprehension of this complex phenomenon. Braudel explains the formation of capitalism in Europe based on the concepts of material life, market economy and capitalism, with the rise of market sociability, essential element of the capitalist circulation. Marx, from the process of primitive accumulation, explains how the conditions for capitalist production are created, in which confront themselves, on the one hand, the capitalist, who owns the means of production, and on the other, the wage-worker. Lastly, we seek in Braudel, Arrighi and Wallerstein a comprehension of the global dynamic of the world-system in the capitalist mode of production, with its hierarchical division
\end{abstract}

1 Doutorando em Economia pela Universidade Federal do Rio Grande do Sul (UFRGS). Mestre em Economia pela Universidade Federal do Rio Grande do Sul, E-mail: henrique.grazziotin@gmail.com 
between center, periphery and semiperiphery, its accumulation systemic cycles and its shift of hegemonic center.

Keywords: World-System. Braudel. Marx. Arrighi. Wallerstein.

Classificação JEL: B51, F50, P16

\section{Introdução}

Este artigo tem como objetivo construir, de forma sintética, uma interpretação acerca da formação do sistema-mundo capitalista e da sua dinâmica com base nos trabalhos de Fernand Braudel, Karl Marx, Giovanni Arrighi e Immanuel Wallerstein. Trata-se de sintetizar os elementos basilares para a compreensão de um fenômeno histórico de alta complexidade, sem a pretensão de esgotá-lo. Primeiramente, buscamos uma possível interpretação, com a tentativa de compatibilização entre as análises históricas e teóricas de Braudel e Marx sobre a emergência do sistema-mundo capitalista. A primeira análise da emergência do sistema-mundo está relacionada ao processo de circulação da produção na forma mercantil, com o surgimento de grandes mercados organizados e do capital comercial e usurário organizado, precursor do capital industrial. Tal interpretação refere-se ao trabalho de Fernand Braudel em seu livro A Dinâmica do Capitalismo, com os conceitos de vida material, economia de mercado e capitalismo (BRAUDEL, 1987).

Entendemos que a forma mercadoria é um dos dois pressupostos básicos para a consolidação do processo de acumulação de capital em escala global, e a abordagem histórica de Braudel sobre a formação das relações de mercado na Europa permite o entendimento desse primeiro pressuposto. $\mathrm{O}$ segundo pressuposto é a separação entre força de trabalho e meios de produção, em que os instrumentos e matériasprimas passam a ser propriedade de uma classe específica: a classe capitalista. Para entender a consolidação do modo capitalista de produção na Europa, buscamos na tradicional abordagem de Marx sobre a acumulação primitiva de capital a compreensão da formação das contradições de classe existentes no bojo da produção capitalista (MARX, 1998). Assim, nos valemos desses dois autores para entender o processo histórico de formação do sistema-mundo capitalista, pois é esse o processo histórico que cria as condições para a existência da acumulação de capital em escala global e é com base nele que a dinâmica do sistema pode ser compreendida.

Cabe ressaltar que os conceitos empregados por Braudel não apresentam paralelo direto na abordagem de Marx, apesar da inegável influência desse autor sobre ele. Precursor da Escola dos Annales, Braudel entende a história não como coleção de feitos de grandes indivíduos, mas sim como a transformação gradual da vida cotidiana. Braudel não trabalha com as mesmas categorias de Marx e sua análise está mais 
voltada para a esfera das hierarquias de poder. No entanto, conforme argumentamos, o processo histórico descrito por esse autor encontra respaldo no trabalho de Marx, no sentido de que se trata da descrição de um mesmo fenômeno a partir de conceitos distintos. Buscamos, neste trabalho, expor os preceitos originais do trabalho de Braudel e discutir sua complementaridade com a abordagem de Marx.

Posteriormente à interpretação da formação do sistema-mundo capitalista, procuramos, através dos autores que tratam especificamente desse tema, entender os movimentos e os ciclos longos que se manifestam na dinâmica global. Por meio da herança teórica de Braudel, que demonstra a mudança dos polos de acumulação ao longo do tempo, Giovanni Arrighi desenvolve a abordagem dos ciclos sistêmicos de acumulação. Estes são longos processos de acumulação de capital que apresentam um centro hegemônico que, inicialmente com uma crise sinalizadora e posteriormente com uma crise terminal, se arrefecem. Assim, na abordagem de Arrighi, surgem sucessivamente novos ciclos sistêmicos de acumulação capitaneados por um novo centro hegemônico (ARRIGHI, 1996). Immanuel Wallerstein, por sua vez, demonstra a necessidade de uma abordagem que leve em consideração o sistemamundo como sistema global para que seja atendido o princípio da totalidade existente nas abordagens marxistas e herdado da filosofia hegeliana (WALLERSTEIN, 1996). Além disso, o autor desenvolve o conceito de hierarquia no sistema-mundo para entender as relações internacionais, alicerçado na lógica capitalista e na exploração entre as nações, com os conceitos de centro, periferia e semiperiferia (WALLERSTEIN, 2000).

Assim, o trabalho a seguir está dividido em quatro seções, além desta introdução. $\mathrm{Na}$ primeira seção, exploramos a interpretação de Braudel sobre a formação da lógica e da sociabilidade mercantil na Europa capitalista; na segunda, explicitamos a abordagem de Marx sobre a acumulação primitiva de capital; e, na terceira, apresentamosos principais conceitos acerca da abordagem do sistema-mundo. A última seção conclui o trabalho resumindo os principais pontos do processo histórico de formação do sistema-mundo e de sua dinâmica.

\section{Braudel: vida material, economia de mercado e capitalismo}

Em A Dinâmica do Capitalismo (1987), Braudel sintetiza sua abordagem acerca da formação do capitalismo na Europa. Nosso objetivo nesta seção é explicitar pontos-chave de sua argumentação, com enfoque no desenvolvimento da sociabilidade mercantil e de uma burguesia mercantil na passagem da sociedade feudal para a capitalista nesse continente. $\mathrm{O}$ argumento que desenvolvemos nesta seção é que emerge, na Europa, uma forma de circulação mercantil mais desenvolvida que as préexistentes em outras regiões, permitindo o surgimento de formas de capital pretéritas 
ao capital industrial, produtor de mais-valor, que são o capital comercial e usurário. Para isso, buscamos sintetizar os principais argumentos presentes nos primeiros dois capítulos da obra $A$ Dinâmica do Capitalismo.

A interpretação da história econômica feita por Braudel rejeita a ideia de que esta deva ser entendida como a "história nobre", a história baseada nos grandes eventos ou na história de certos indivíduos. Ao contrário, a história econômica é abordada por Braudel a partir do método da Escola dos Annales, em que se busca "a compreensão da evolução histórica nas transformações da vida quotidiana, por oposição à historiografia dos grandes homens e dos seus feitos" (FARIA, 2007). Com base nessa concepção, surge o conceito de vida material, em que o relevante é compreender as rotinas e os hábitos da vida econômica que estão fora da consciência clara dos seres humanos. Esse espectro inconsciente da vida humana são as estruturas do cotidiano, que evoluem gradualmente ao longo do tempo e apresentam certa inércia em relação ao passado. ${ }^{2}$ Ao explicitar seu método de análise histórica, Braudel (1987, p. 13-4, grifos nossos) afirma o seguinte:

Por minha parte, fiquei nos critérios concretos. Parti do cotidiano, daquilo que, na vida, se encarrega de nós sem que saibamos sequer: o hábito - melhor, a rotina - mil gestos que florescem, se concluem por si mesmos e em face dos quais ninguém tem que tomar uma decisão, que se passam, na verdade, fora de nossa plena consciência. Creio que a humanidade está pela metade enterrada no cotidiano. Inumeráveis gestos herdados, acumulados a esmo, repetidos infinitamente até chegarem a nós, ajudam-nos a viver, aprisionam-nos, decidem por nós ao longo da existência. São incitações, pulsões, modelos, modos ou obrigações de agir que, por vezes, e mais frequentemente do que se supõe, remontam ao mais remoto fundo dos tempos. Muito antigo e sempre vivo, um passado multissecular desemboca no tempo presente como o Amazonas projeta no Atlântico a massa enorme de suas águas agitadas.

Sendo assim, a vida material faz parte do inconsciente da vida humana. Braudel afirma que, além de rotineiros, os seres humanos são inventores, pois há também a parte consciente, racional, deliberada da vida humana. Coexiste a vida material inconsciente e a agência humana, deliberada e consciente. No entanto o enfoque de

2 Cabe ressaltar que o conceito de vida material de Braudel guarda alguma semelhança com a definição de instituições em Veblen, como sendo "hábitos de pensamento e comportamento compartilhados por uma generalidade de seres humanos”. Da mesma forma que em Braudel, as instituições, em Veblen, evoluem de forma gradual e apresentam como característica essencial a dependência das trajetórias históricas (path-dependence). Ao mesmo tempo, os dois conceitos guardam uma série de diferenças básicas, como o fato de a vida material estar relacionada diretamente a formas de subsistência na abordagem de Braudel, enquanto o memso não acontece na interpretação vebleniana. Portanto, apesar das semelhanças, a relação entre instituições e vida material deve ser tratada com cautela. 
Braudel é na primeira, ou seja, nas questões rotineiras da vida humana. Os elementos constitutivos da vida material são tanto de ordem biológica, natural, quanto de ordem social, e estão sempre articulados de forma conjunta, sendo a vida material um conjunto de múltiplas determinações.

Um dos primeiros elementos atribuídos à vida material por Braudel é o impulso biológico de reprodução humana. $\mathrm{O}$ impulso da natalidade, juntamente com as mazelas que limitam a população, como as guerras, as doenças e as penúrias da fome e da escassez de recursos e de condições sanitárias, criam a complexa dinâmica demográfica. "Essa matéria humana em perpétuo movimento comanda, sem que os indivíduos tomem consciência disso, uma boa parte dos destinos de conjuntos de seres vivos" (BRAUDEL, 1987). Marx (1998), ao tratar da lei geral da acumulação capitalista e da tendência a uma superpopulação relativa no processo de acumulação de capital, afirma que não há uma lei "natural” da demografia. Esta sempre depende do desenvolvimento das forças produtivas e do modo de produção existente. Dessa forma, a dinâmica demográfica apresenta uma série de determinantes de ordem social, além desse impulso biológico natural e inerente à espécie humana da sexualidade e da reprodução.

O padrão de alimentação das sociedades humanas, com o consumo e a produção de alimentos específicos, também faz parte do que Braudel entende por vida material. São importantes fluxos da história a descoberta, o manuseio e o surgimento de certas espécies de alimentos como sal, açúcar, trigo, café, chá e álcool. Desde a Revolução Neolítica (CHILDE, 1950; 1978), a domesticação de animais e o domínio da atividade agrícola permitiram à espécie humana não só o controle qualitativo da sua alimentação como também o estabelecimento em regiões específicas. Destaca-se também como importante elemento da vida material o vestuário, que reflete não só as condições climáticas sob as quais se encontra a espécie humana, mas também questões culturais, de técnicas produtivas de tecelagem e de matérias-primas disponíveis. Ainda na esfera da vida cotidiana, as diferentes formas de alojamento das populações humanas também são um aspecto relevante, análogo aos anteriores. Todos esses aspectos refletem necessidades vitais e biológicas dos seres humanos, mas que, em sua manifestação no concreto, no real, sempre assumem formas sociais específicas, envolvendo relações sociais próprias dessas formas.

Por fim, fazem parte da vida material as técnicas e os instrumentos desenvolvidos pelos seres humanos. São elementos que estão relacionados à busca pelo controle e pelo uso dos elementos do exterior, do ambiente para usufruto humano, criando os valores de uso necessários para a sua sobrevivência. É pela necessidade de produção dos seus meios de subsistência que a espécie humana domina o ambiente. Esse tema é tratado com especial atenção por Marx ao tratar do trabalho 
humano, dos processos de produção e de seus diferentes componentes. ${ }^{3} \mathrm{O}$ desenvolvimento das forças produtivas corresponde à maior capacidade de controle dos elementos naturais em favor do ser humano, mas este desenvolvimento também assume diferentes formas sociais, que lhe circunscrevem em relações sociais que o determinam de diferentes maneiras. No modo de produção capitalista, o desenvolvimento das forças produtivas, por exemplo, serve à acumulação de capital em escala ampliada, e não à emancipação do ser humano.

A delimitação dos limites dessa esfera rotineira e habitual da vida humana não é tarefa simples. Um exemplo é a própria criação de técnicas e de instrumentos. Para criá-los, é necessária uma ação racional, deliberada e consciente, orientada por um fim específico, o que não se insere na atividade habitual e rotineira. Sobre essa dificuldade de definição, Braudel afirma o seguinte:

$\mathrm{Na}$ realidade, o habitual invade o conjunto da vida dos homens, difunde-se nela como a sombra da tarde enche uma paisagem. Mas essa sombra, essa falta de memória e de lucidez, admitem simultaneamente zonas menos iluminadas e zonas mais claras do que outras. Entre sombra e luz, entre rotina e decisão consciente, seria importante marcar o limite. Uma vez reconhecido, ele permitiria distinguir o que está à direita e o que está à esquerda do observador, ou, melhor, acima e abaixo dele (BRAUDEL, 1987, p. 20).

Braudel insere ainda, na sua explanação acerca da vida material, as moedas e as cidades, devido ao fato de que são elementos que pertencem aos primórdios da vida humana e permanecem até hoje como parte da vida contemporânea. "A moeda é uma invenção muito velha, se entendo por moeda todo o meio que acelera a troca" (BRAUDEL, 1987). De fato, toda mercadoria que assume a função de equivalente geral em uma sociabilidade mercantil assume a forma dinheiro, que é a mercadoria na qual se expressa o valor de troca das demais (MARX, 2008, cap. 1). Embora a sociabilidade mercantil só venha a emergir enquanto forma global de sociabilidade posteriormente, com o pleno desenvolvimento dos mercados globais, as relações mercantis eventuais, elementares, são parte da vida humana desde muito antes da formação do modo de produção capitalista.

As relações mercantis elementares são o que Braudel denomina "economia de mercado", enquanto as relações de acumulação a partir do comércio estão presentes no conceito de "capitalismo" em sua teorização. Na descrição de Braudel, é a economia de mercado que separa a vida material, esfera ligada à subsistência, da vida

3 "O que distingue as diferentes épocas econômicas não é o que se faz, mas como, com que meios de trabalho se faz. Os meios de trabalho servem para medir o desenvolvimento da força humana de trabalho e, além disso, indicam as condições sociais em que se realiza o trabalho.” (MARX, 2008, p. 214) 
econômica, em que produção e consumo se encontram na sociabilidade mercantil. ${ }^{4}$ Acima da economia de mercado, há o que Braudel define como capitalismo, que são as relações mercantis marcadas por relações de poder e dominação oligopolista ou monopolista. A "economia de mercado" é o único dos três conceitos de Braudel que se passa na esfera pública, sendo transparente. Os outros dois, a vida material e o capitalismo, acontecem em esferas privadas, sendo a primeira relacionada à subsistência, e o segundo, às formas de poder econômico que estruturam formas hierárquicas de dominação (FARIA, 2007). Definiremos, a seguir, os conceitos de economia de mercado e capitalismo, buscando descrever a sua interpretação da emergência da sociedade capitalista na Europa a partir do século XV.

A economia de mercado é, para Braudel, a ligação entre a produção individual e o consumo através dos mercados. Sua existência faz com que a produção seja cada vez mais voltada à geração de valores de troca ao invés da produção voltada aos valores de uso. Braudel distingue dois registros da economia de mercado: um registro inferior (mercados, lojas, camelôs) e um superior (Feiras e Bolsas). A diferença essencial entre esses dois registros é que o segundo é dominado por grandes comerciantes atacadistas e estão abertas todos os dias, funcionando em datas fixas durante determinado período de tempo. Portanto, economia de mercado é a sociabilidade mercantil que une a produção e o consumo numa sociedade em que há divisão social do trabalho. Nos termos de Marx, é a esfera de circulação da produção propriamente dita.

Para entender o conceito de capitalismo em Braudel, o autor diferencia a economia de mercado em dois tipos: as do tipo A são as trocas quotidianas do mercado, trocas locais e de pouca distância. Elas são "transparentes", conhecendo-se a margem de lucro de antemão, ocorrem com regularidade e sem surpresas, como, por exemplo, no mercado de um burgo. As do tipo B, diferentemente, são trocas que ocorrem em longas distâncias e nas quais há a figura de um intermediário, de um comerciante capaz de perturbar, de manobrar e de influenciar o mercado (BRAUDEL, 1987; FARIA, 2007). Nesse segundo tipo, há a predominância da troca desigual que garante os lucros comerciais desse "atravessador" das relações mercantis. Esse tipo de mercado gera uma esfera de circulação de caráter distinto do primeiro, pois liga mercados locais de forma internacional, em que os capitais comerciais

4 "O artesão itinerante, que vai de burgo em burgo oferecer seus modestos serviços de reempalhador de cadeiras ou de limpa-chaminés, embora um consumidor medíocre, pertence, no entanto, ao mundo do mercado; deve pedir-lhe o seu alimento cotidiano. Se ele conservou os vínculos com sua terra natal e no momento da colheita ou da vindima retorna à sua aldeia, volta a ser camponês e transpõe a fronteira do mercado, mas no sentido inverso. O camponês que comercializa ele próprio, regularmente, uma parte da sua colheita e compra ferramentas, vestuário, já faz parte do mercado. Aquele que só vai ao burgo vender algumas mercadorias miúdas, ovos, uma galinha, a fim de obter algumas moedas necessárias ao pagamento de seus impostos ou à compra de uma relha de charrua, esse toca somente a fronteira do mercado. Permanece na enorme massa do autoconsumo." (BRAUDEL, 1987, p. 21). 
operam através do comércio desigual entre as regiões. Formam-se rotas internacionais de comércio com lucros distintos daqueles do mercado de tipo A.

O segundo tipo de mercado seria o que Braudel chama de "contramercado" ou "mercado privado", em distinção aos "mercados públicos" locais. O contramercado é marcado pelas trocas desiguais, em que a concorrência não tem lugar devido às vantagens do comerciante de ter rompido o vínculo entre o produtor e o destinatário da mercadoria e de ter dinheiro para compras à vista. Por ser marcado pelas longas distâncias, escapa das regras e controles habituais existentes no mercado público e é dominado por poucos comerciantes, que acumulam capitais com lucros extraordinários, anormais. Assim, distingue-se o grande comerciante, que opera no contramercado, do pequeno comerciante (BRAUDEL, 1987).

O conceito de capitalismo para Braudel é a relação de poder exercida por essa seleta burguesia mercantil que, ao dominar o contramercado, se relaciona com o Estado de forma a garantir sua posição hierárquica e de privilégio. Isso se sustenta pela massa de capitais acumulada no comércio internacional. Esses comerciantes praticam, além disso, o comércio de dinheiro e, após acumularem tesouro, também o crédito usurário. Braudel, ao tratar das questões de poder prioritariamente, aponta para a importância da relação entre essa burguesia mercantil e o Estado, na qual este pode ser favorável ou hostil àquela. A hierarquia política das sociedades, no capitalismo, é dominada pela hierarquia econômica, em que o sucesso de longas cadeias familiares forma uma burguesia que parasita a nobreza. Pode-se dizer que o capitalismo surge quando há uma ordem social estável, complacência do Estado e uma hierarquia econômica formada pelo sucesso da burguesia comercial no contramercado. O capitalismo, por sua vez, se sustenta na economia mercantil, sendo a última sustentada na vida material.

Acima da massa imensa da vida material de todos os dias, a economia de mercado estendeu suas malhas e manteve em vida suas redes. E foi, habitualmente, acima da economia de mercado propriamente dita que o capitalismo prosperou. Poderia dizer-se que a economia do mundo inteiro é visível num mapa em relevo. (BRAUDEL, 1987, p. 33) 
Figura 1 - A tripartição da sociedade capitalista segundo Braudel

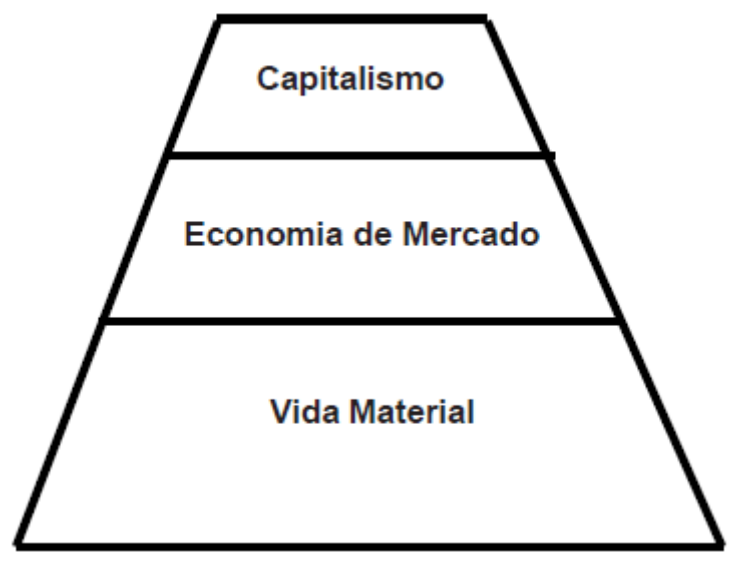

Fonte: FARIA (2007)

\section{Marx: capital comercial, capital usurário e acumulação primitiva}

A descrição de Braudel do capitalismo tendo por base o desenvolvimento das relações mercantis é análoga ao surgimento do capital comercial, do capital de comércio de dinheiro e do capital usurário, que são formas pré-capitalistas de acumulação de excedente em Marx. ${ }^{5}$ No modo de produção capitalista, Marx descreve o capital comercial como autonomização do capital-mercadoria, forma do capital industrial, produtor de mais-valor, assim como descreve o capital de comércio de dinheiro e o capital portador de juros como autonomização do capital-dinheiro. No entanto, estes capitais já existiam anteriormente ao modo de produção capitalista, porém com fundamentos distintos. Com o surgimento do capital industrial, eles deixam de ser a forma dominante de acumulação e passam a cumprir funções técnicas da esfera da circulação do capital industrial. Porém cabe entender os fundamentos dados por Marx a essas formas pretéritas de capital.

O capital comercial tem como condição básica de existência a sociabilidade mercantil, independentemente do modo de produção existente. Por pertencer exclusivamente à esfera da circulação, as relações de produção por trás do processo de produção da mercadoria não apresentam qualquer relação com a formação dessa

5 “O capital portador de juros, ou como podemos denominá-lo em sua forma antiga, o capital usurário, pertence, com seu irmão gêmeo, o capital comercial, às formas antediluvianas do capital, que por longo tempo precedem o modo de produção capitalista e se encontram nas mais diversas formações econômicas da sociedade.” (MARX, 1986, p. 101) 
forma de capital, requerendo, portanto, apenas o acúmulo de certa quantia de dinheiro e a existência de mercados. Todavia, por ser um capital, sua lógica é a da acumulação de valores de troca (D-M-D') e não de obtenção de valores de uso (M-D-M). Uma vez que esse capital é exclusivo da esfera da circulação de mercadorias, o lucro comercial obtido tem como fonte necessariamente a troca desigual e não a troca por equivalentes de valor (MARX, 1986). Nesses termos, a descrição de Braudel sobre a burguesia mercantil é compatível com a de Marx sobre o capital mercantil précapitalista. Essa burguesia mercantil emergente com o "capitalismo" em Braudel é a mesma classe que, a partir do capital comercial expansivo do comércio internacional, passa a acumular capital por intermédio do comércio desigual praticado em longas distâncias, com a arbitragem entre preços de diferentes mercados. Essa acumulação é relevante, pois constitui uma forma de acúmulo de riqueza anterior à formação do modo de produção capitalista, cujos capitais serão empregados posteriormente no processo de produção capitalista.

Outra forma antediluviana de capital que aparece na interpretação de Braudel e que encontra respaldo na teoria de Marx é a do capital usurário. No capitalismo de Braudel, os grandes comerciantes não negociam exclusivamente mercadorias, mas também dinheiro. O capital usurário, de acordo com Marx, tem como fundamento principal o excedente produzido por camponeses proprietários de seus próprios meios de produção durante o modo de produção feudal na Europa. A apropriação pelo capitalista usurário desse excedente constitui uma forma de exploração que apresenta papel particular na transição do modo de produção feudal na Europa para o modo capitalista: em primeiro lugar, assim como o capital comercial, essa forma de acumulação aglutina capitais que serão empregados posteriormente na produção manufatureira e industrial; em segundo, estagna o desenvolvimento das forças produtivas da produção camponesa. Portanto o capital usurário, ao mesmo tempo em que funciona de forma parasitária, apropriando-se do excedente produzido pelo campesinato e estagnando as forças produtivas, permite a acumulação necessária para o modo de produção capitalista posterior (MARX, 1986).

Conforme explicitado por Marx, a emergência do modo de produção capitalista não se explica pelo crescimento do capital comercial e usurário exclusivamente. Ao contrário, capital comercial só é a forma dominante de acumulação enquanto não há a consolidação do capital industrial produtor de mais-valor. Com a consolidação do modo de produção capitalista, o capital comercial passa, gradualmente, a cumprir as funções técnicas de circulação necessárias à circulação do capital industrial, assim como os juros provenientes da usura e do comércio de dinheiro passam a ter fundamentação no excedente produzido por esse mesmo capital, o mais-valor. Assim, a dominação do capital comercial, de acordo com Marx, está inversamente relacionada ao desenvolvimento do processo de produção capitalista (MARX, 1986). A sua 
importância relativa é menor à medida que se desenvolvem as forças produtivas. A dominação completa do capital industrial em relação ao capital comercial se consolida com o modo de produção especificamente capitalista, em que não há apenas a subsunção formal do trabalho ao capital, mas a subsunção real, com o emprego de maquinaria e com a consolidação da grande indústria no processo produtivo. Portanto, para entender a dinâmica do sistema-mundo, não basta compreender somente as formas pretéritas de capital no período de formação do capitalismo global, mas também a formação do modo capitalista de produção.

Marx argumenta que o processo histórico que leva ao modo de produção capitalista é um processo violento, marcado pela expropriação da propriedade individual de camponeses e artesãos e pela decomposição do sistema feudal. Esse processo é chamado de "acumulação primitiva", pois é através dele que se criam as condições para que trabalhadores assalariados se encontrem no mercado à disposição de capitalistas detentores dos meios de produção. Essa é a condição necessária para que haja a subsunção formal do trabalho ao capital, permitindo a divisão técnica do trabalho, a cooperação dos meios de produção e, posteriormente, com o desenvolvimento das forças produtivas, a subsunção real do trabalho ao capital por meio da maquinaria. Portanto, o sistema-mundo capitalista necessita desse processo para que a produção assuma a forma capitalista.

A acumulação de capital pressupõe o mais-valor e o mais-valor pressupõe a existência de capital no modelo teórico de Marx. Assim, há um aparente ciclo vicioso na sua formulação, sendo necessário explicar a formação do modo de produção capitalista de outra forma: a acumulação primitiva de capital. Ela é definida por Marx da seguinte forma:

O processo que cria o sistema capitalista consiste apenas no processo que retira do trabalhador a propriedade dos seus meios de trabalho, um processo que transforma em capital os seus meios de subsistência e os de produção e converte em assalariados os produtores diretos. A chamada acumulação primitiva é apenas o processo histórico que dissocia o trabalhador dos meios de produção. É considerada primitiva porque constitui a pré-história do capital e do modo de produção capitalista (MARX, 1998, p. 828).

Esse elemento não é tratado por Braudel, pois esse autor enfatiza a esfera da circulação, a formação das relações mercantis. A interpretação de Braudel, portanto, precisa ser complementada pelo processo de acumulação primitiva para que se possa entender tanto a constituição da forma mercantil de circulação quanto do modo capitalista de produção, dois elementos essenciais do processo de acumulação de capital existente no sistema-mundo moderno, fundamento básicodos ciclos sistêmicos de acumulação. 
Marx afirma que é em virtude da dissolução do sistema feudal existente na Europa que se criam os elementos necessários para a formação da sociedade capitalista. Para vender sua força de trabalho, o trabalhador não deve ser mais vinculado à gleba ou ser escravo/servo. Ele deve ser duplamente livre: livre por não ser parte direta dos meios de produção (servo ou escravo) e livre dos meios de produção, não sendo proprietário destes. Além disso, o trabalhador deve se livrar do domínio das corporações e de seus regulamentos, aos quais se subordinavam os aprendizes e os oficiais da produção pré-capitalista. Entretanto esses dois movimentos históricos libertação da servidão e da coerção corporativa - ocorreram de forma violenta, com a expropriação e a destruição das condições de vida baseadas nas instituições feudais. Da mesma forma, o capitalista industrial se sobrepõe às corporações oficiais com a manufatura baseada no trabalho assalariado, rompendo com as condições feudais. Portanto o início da sociedade capitalista deve ser compreendido a partir de um processo histórico que transforma a sujeição do trabalhador, com a metamorfose da exploração feudal para a exploração capitalista, processo que é assentado na violência.

A acumulação primitiva descrita por Marx compreende o período que vai do século XIV até o século XVI. No entanto, seus prenúncios se apresentam de longa data, o que leva a crer que não se trata de um processo momentâneo, mas lento e gradual. Toda a descrição de Marx (1998, p. 827-77) refere-se especificamente à Inglaterra, que viria a ser, mais tarde, o centro hegemônico do capitalismo industrial. Sendo assim, essa descrição apresenta momento histórico específico, não podendo ser generalizada como "processo natural" pelo qual uma sociedade pré-capitalista deva necessariamente passar. ${ }^{6}$ Nossa descrição do processo segue a de Marx, tratando inicialmente da formação da classe trabalhadora, com a expropriação dos camponeses, as leis contra a vadiagem e a formação de um mercado interno para o capital industrial e, posteriormente, da formação da classe capitalista, com o arrendatário capitalista e o capitalista industrial.

No início do século XV, a maior parte da população da Inglaterra consistia em camponeses proprietários, tendo a servidão típica do feudalismo praticamente

6 Embora Marx afirme que a experiência histórica da Inglaterra possa ser considerada a "forma clássica" da acumulação primitiva, não significa que o mesmo processo se repita em outras nações. Pelo princípio da totalidade, é necessário entender o movimento do sistema-mundo como um todo e, a partir dele, a posição hierárquica de cada nação no processo de acumulação de capital em escala global. Wallerstein (2000) critica as abordagens que analisam, exclusivamente na esfera nacional, a sucessão de modos de produção, pois é necessário ter como unidade de análise não a nação, mas o sistema-mundo. Para o Brasil, o erro de estabelecer um modelo "etapista" baseado em modos de produção naturalmente sucessivos para interpretar países periféricos foi criticado por Caio Prado Júnior em $A$ revolução brasileira (2004). Uma interpretação do processo de "Revolução Burguesa" no Brasil mais coerente, com o estabelecimento de uma sociedade capitalista concorrencial, é a de Florestan Fernandes em A revolução burguesa no Brasil (2005), pois não há o pressuposto da necessidade de transição de um regime feudal para um regime capitalista na esfera nacional. 
desaparecido. Esses camponeses eram responsáveis pelo trabalho nas terras de sua propriedade, que mantinham através de certo título feudal, e dispunham também de terras comuns das quais usufruíam e eram coproprietários, mantendo gado e obtendo outros meios de subsistência. Nesse período, passou a surgir um proletariado com a dissolução das vassalagens do sistema feudal que constituía a massa que passava a formar um mercado de trabalho e se aglomerar nos meios urbanos. Porém esse proletariado foi intensificado principalmente através do processo de expropriação dos camponeses proprietários de terra.

As terras usurpadas e a expulsão dos camponeses foram principalmente motivadas pelo florescimento e pelo crescimento da manufatura de lã, cujos preços cresceram no período. Esse processo violento teve como sujeito a própria nobreza feudal do período, que buscava enriquecer com esse segmento. $\mathrm{O}$ famoso processo de cercamento das terras comuns é a principal forma que assumiu a expropriação dos camponeses, pois havia a necessidade de pastagens para a criação de ovelhas e, consequentemente, para a produção de lã. A atividade de criar ovelhas, por requerer pouca mão de obra, não só tirava do camponês a sua propriedade individual, assentada no seu trabalho pessoal, como também gerava um contingente de trabalhadores desprovidos de meios de produção, cuja única escolha seria se juntar ao meio urbano na busca de trabalho assalariado.?

A expropriação dos camponeses foi ainda impulsionada pela Reforma da Igreja Católica no século XVI, pois a Igreja era grande proprietária feudal do solo inglês. A supressão dos conventos levou a uma maior expropriação e a um aumento dos saques de terra. Os bens eclesiásticos foram doados ou vendidos a especuladores, agricultores ou burgueses, que expulsaram os camponeses e fundiram as suas terras, expandindoas. Seus efeitos para a produção de uma classe trabalhadora foram consideráveis também devido ao fato de que a Igreja constituía o fundamento religioso das relações de propriedade feudais. A sua queda abalou a sustentação dessas relações, que dariam lugar ao regime da moderna propriedade privada desprovida de titulações feudais.

Um terceiro impulso descrito por Marx a esse processo foi a "Revolução Gloriosa”, que tolheu o poder da monarquia, aumentando o poder dos proprietários do mais-valor, de nobres e capitalistas. A partir daí, expandiram-se os processos de expropriação em escala ainda maior. Tal processo era favorecido pelos capitalistas burgueses, pois eles buscavam transformar a terra em artigo de comércio e ampliar a exploração agrícola e os suprimentos para o proletariado. No século XVIII, a própria

7 A expropriação dos camponeses e pequenos arrendatários causou certa reação no período de Henrique VII, tanto pelo descontentamento dos expropriados quanto pela legislação, que buscou mitigar os seus impactos (MARX, 1998, p. 832-33). Medidas contra a expropriação das terras comuns e contra a expansão das pastagens foram tomadas, porém sem resultados, devido ao seu baixo efeito prático. Proibiu-se a destruição de casas de camponeses e houve a limitação legal do número de ovelhas por proprietário, assim como a fixação da relação entre a área de lavoura e de pastagem. 
lei torna-se veículo de expropriação através de leis relativas ao cercamento das terras comuns, em que o roubo dessas terras justificava-se pela argumentação de que elas eram, na verdade, propriedade privada dos lordes latifundiários. $O$ espaço anteriormente ocupado pelos camponeses passou a ser ocupado por grandes arrendatários capitalistas, empregando menor quantidade de trabalhadores e pagando a renda da terra ao latifundiário.

O último grande processo retratado por Marx é o de "limpeza das propriedades", que constituiu a derrubada violenta das moradias dos trabalhadores agrícolas, proprietários individuais de suas terras, fazendo com que, necessariamente, deixassem de habitá-las. A destruição das choupanas fazia com que a terra lavrada pelo trabalhador deixasse de ser sua habitação. A consequência direta deste processo foi a mesma dos anteriores: a transformação dos trabalhadores individuais, proprietários de suas terras, em proletariado. Para Marx (1998, p. 847),

O roubo dos bens da Igreja, a alienação fraudulenta dos domínios do estado, a ladroeira das terras comuns e a transformação da propriedade feudal e do clã em propriedade privada moderna, levada a cabo com terrorismo implacável, figuram entre os métodos idílicos da acumulação primitiva. Conquistaram o campo para a agricultura capitalista, incorporaram as terras ao capital e proporcionaram à indústria das cidades a oferta necessária de proletários sem direitos.

A massa proletária expulsa das terras, sem poder ser absorvida pela manufatura nascente na mesma velocidade, constituiu um amplo estrato social urbano desprovido de condições básicas de subsistência. Por força das circunstâncias, aumentou o número de mendigos e de ladrões nas cidades. A consequência desse fenômeno foi a emergência de uma legislação contra a vadiagem na Europa ocidental de teor bastante repressivo (MARX, 1998, p. 848). ${ }^{8}$ Nessas leis, destacava-se a violência empregada de forma brutal contra os chamados "vagabundos". Marx retrata as principais leis entre os séculos XVI e XVII.

\begin{abstract}
Assim, a população rural, expropriada e expulsa de suas terras, compelida à vagabundagem, foi enquadrada na disciplina exigida pelo sistema de trabalho assalariado, por meio de um grotesco terrorismo generalizado que empregava o açoite, o ferro em brasa e a tortura (MARX, 1998, p. 850-51).
\end{abstract}

8 "Os ancestrais da classe trabalhadora atual foram punidos inicialmente por se transformarem em vagabundos e indigentes, transformação que lhes era imposta. A legislação os tratava como pessoas que escolhem propositalmente o caminho do crime, como se dependesse da vontade deles prosseguirem trabalhando nas velhas condições que não mais existiam.” (MARX, 1998, p. 848). 
A classe trabalhadora era diminuta e ainda em formação entre os séculos XV e XVII, tendo sido utilizadas, nesse período, diversas leis para manter os salários baixos, expandindo o processo de acumulação. A subordinação do trabalho ao capital era meramente formal, inexistindo ainda relações tipicamente capitalistas. $\mathrm{O}$ processo de acumulação também não era capaz de gerar uma superpopulação relativa que levasse à redução dos salários. Portanto, a acumulação era possibilitada através de leis que estabeleciam o salário máximo permitido e que perseguiam coligações e associações de trabalhadores.

A expansão da classe trabalhadora também teve como consequência a expansão do mercado interno, pois os camponeses, que produziam antes os seus próprios meios de subsistência, passavam agora a ter de acessar a produção na forma mercadoria, pois haviam sido desapropriados de seus meios de produção. Os artigos antes produzidos individualmente passaram a ser artigos de manufatura. Assim, o processo de acumulação primitiva não só criou uma classe de trabalhadores assalariados disposta a vender sua força de trabalho ao capitalista, como também criou o mercado interno necessário para a realização do capital industrial. ${ }^{9}$

A emergência da classe capitalista, por sua vez, decorreu dos mesmos processos que formaram a classe trabalhadora. Já vimos, com base em Braudel, a emergência do capitalista comercial e usurário a partir da intermediação comercial e financeira nos mercados. Resta-nos entender como surgiram os capitalistas arrendatários de terras e o capitalista industrial, os capitalistas da esfera da produção.

No momento em que há a expropriação de terras dos camponeses, formam-se grandes proprietários de terras, os latifundiários. A formação do arrendatário capitalista, todavia, é um processo lento e gradual. O arrendatário é o capitalista que arrenda as terras do senhor, proprietário das terras, empregando força de trabalho e expandindo seu capital, mas pagando por isso a renda da terra. Marx sustenta que o surgimento dessa classe parte dos próprios servos e camponeses, que se emancipam de diferentes formas. Alguns permanecem trabalhando nas terras cuja propriedade é do senhor, organizando o trabalho assalariado. Logo se tornam parceiros, forma muito próxima do arrendatário capitalista em que o capital empregado é parte do parceiro e parte do senhor. No entanto, conforme afirma Marx (1998, p. 856),

9 "Antes a família camponesa produzia e elaborava os meios de subsistência e matérias-primas, que eram, na sua maior parte, consumidos por ela mesma. Esses meios de subsistência e matérias-primas transformam-se agora em mercadorias; o arrendatário vende-as no mercado gerado pelas manufaturas. Fios, tecidos de linho, panos grosseiros de lã - coisas cujas matérias-primas estavam ao alcance de toda família camponesa, fiadas e tecidas por esta para o próprio consumo - são agora artigos de manufatura que encontram seu mercado exatamente nos distritos rurais. A numerosa clientela antes extremamente fragmentada, dependente de uma quantidade imensa de pequenos produtores que trabalhavam por sua própria conta, concentra-se agora num vasto mercado, abastecido pelo capital industrial." (MARX, 1998, p.861). 
Essa forma desaparece rapidamente na Inglaterra, para dar lugar ao arrendatário propriamente dito, que procura expandir seu próprio capital empregando trabalhadores assalariados e entrega a landlord uma parte do produto excedente, em dinheiro ou em produtos, como renda da terra.

A classe de arrendatários capitalistas, que existe de forma modesta na Inglaterra a partir do século XV, aumenta consideravelmente com a revolução agrícola ao longo do século XVI. Essa revolução consiste na melhoria dos métodos de cultura, na maior cooperação, na maior concentração de meios de produção e, através do aumento da produtividade do trabalho rural, libera trabalhadores rurais, que se tornam parte da massa do proletariado urbano. Dessa maneira, ao mesmo tempo em que os trabalhadores rurais perdem seus empregos, aumentam os lucros dos arrendatários capitalistas. Dois outros fatores são importantes para a lucratividade do arrendatário capitalista. O primeiro é a apropriação das terras comuns, que permite ampliação da produção de gado e de adubo para expandir a produção agrícola; o segundo, os contratos de arrendamento, que apresentavam prazos muito longos. Esse último, devido à depreciação do dinheiro ao longo do tempo, expandia os lucros dos arrendatários de duas formas: através da redução do salário real dos trabalhadores rurais e da redução real da renda da terra paga ao proprietário, uma vez que essas quantias eram fixadas em termos nominais.

Os capitalistas industriais também surgem com a dissolução das relações feudais. O capital-dinheiro gerado pelas formas pré-capitalistas do capital usurário e do capital comercial, cuja formação e ascensão são explanadas por Braudel, era impedido de assumir a forma de capital industrial devido aos vínculos feudais e às organizações corporativas, dominantes da produção manufatureira. No entanto, com a dissolução das vassalagens e a expropriação das populações rurais, esse processo tornou-se possível. Conforme afirma Marx (1998, p. 864), "as novas manufaturas instalaram-se nos portos marítimos ligados ao comércio de exportação ou em pontos do interior do país fora do controle do velho sistema urbano e da organização corporativa". Passa a ocorrer, na Inglaterra, um conflito entre as cidades corporativas e esses novos centros manufatureiros, ligados ao capital comercial. Assim, o capital acumulado através do grande comércio de mercadorias e de dinheiro passa a ser aplicado como capital industrial, produtor de mais-valor, através da exploração do trabalho assalariado disponível no proletariado liberado pela acumulação primitiva.

Entre os que assumem o papel de pequenos capitalistas industriais estão antigos mestres de corporação, artesãos independentes e ainda assalariados. A sua transformação em capitalistas rudimentares, com a exploração progressiva do trabalho assalariado e a gradual acumulação de capital, permitiu que assumissem realmente a figura de capitalistas industriais, com o rompimento das barreiras feudais e a expansão 
do mercado consumidor urbano. Assim, tanto gradualmente, através desses pequenos capitalistas, como através dos grandes comerciantes, instaura-se o capital industrial na Inglaterra. O seu desenvolvimento levará à queda gradual do capital comercial como forma dominante de acumulação e, no momento em que a Inglaterra passa a ser o centro hegemônico da acumulação capitalista mundial, é esse capital industrial o principal responsável pelos ciclos sistêmicos de acumulação e não mais o antigo capital comercial.

Dessa forma, Marx demonstra, através de argumentos históricos, que a passagem do modo de produção feudal para o modo de produção capitalista na Inglaterra criou uma classe capitalista cujo capital era aplicado em atividades comerciais e financeiras que já existiam anteriormente ou em atividades produtivas, como a produção agrícola por meio do arrendamento e a produção industrial baseada na manufatura e, posteriormente, na maquinaria e na grande indústria. Além disso, criou uma classe de trabalhadores livres desprovidos dos meios de produção para produzir sua própria subsistência. Tal dissociação é uma condição básica para o processo de acumulação de capital, que, no sistema-mundo, toma proporções globais e está na base dos ciclos sistêmicos de acumulação. Entretanto a acumulação primitiva apresenta um escopo mais amplo, principalmente em razão do período nascente do capitalismo industrial. Nele, há o aumento de importância do sistema colonial, da dívida pública, do sistema tributário, do protecionismo, do trabalho infantil e do tráfico de escravos. Estes são todos elementos de violência e de aplicação da força do Estado para instituir o modo de produção capitalista nos países centrais, acelerando a superação do feudalismo. "A força é o parteiro de toda sociedade velha que traz uma nova em suas entranhas. Ela mesma é uma potência econômica” (MARX, 1998, p. 864).

O sistema colonial está diretamente relacionado à expropriação de países periféricos no sistema-mundo, através da descoberta de ouro e de prata na América, das pilhagens e da escravização das populações indígenas e africanas, seguidas de um processo de guerra comercial entre as nações europeias. Assim, a relação de dominação em nível global também foi relevante para a constituição de um sistemamundo capitalista, pois a pilhagem gerada pela colonização foi um dos principais elementos da acumulação primitiva, impulsionando o capital industrial. $\mathrm{O}$ sistema colonial cristão, de acordo com Marx, foi marcado pela violência através da exploração e da escravização, com um comércio desenvolvido de seres humanos como o exercido pelos holandeses no século XVII. Portanto o colonialismo representa parte importante do processo de acumulação primitiva e a relação que se estabelece entre as diversas nações que fazem parte do sistema-mundo tem importância desde o surgimento desse sistema. A sua emergência é marcada pela violência: 
Com tão imenso custo, estabeleceram-se as "eternas leis naturais" do modo capitalista de produção, completou-se o processo de dissociação entre trabalhadores e suas condições de trabalho, os meios sociais de produção e de subsistência se transformaram em capital, num polo, e, no polo oposto, a massa da população se converteu de assalariados livres em "pobres que trabalham”, essa obra-prima da indústria moderna. Se o dinheiro, segundo Augier, "vem ao mundo com uma mancha natural de sangue numa de suas faces", do capital, ao surgir, escorrem sangue e sujeira por todos os poros, da cabeça aos pés (MARX, 1998, p. 873-4).

\section{A dinâmica do sistema-mundo com base em Braudel, Arrighi e Wallerstein}

De forma geral, buscamos, com base em Marx e Braudel, compreender os elementos básicos do processo histórico de formação do sistema-mundo capitalista. Braudel mostra a importância da consolidação da sociabilidade mercantil em escala global, enquanto Marx esclarece o processo de transição para o modo de produção capitalista. Estão dadas as condições para um processo de acumulação de capital cuja dinâmica é global, com a existência de polos de acumulação, responsáveis por criar relações hierárquicas entre determinadas regiões, e ciclos de acumulação que levam a períodos de expansão e a períodos de crise. Para compreender essa dinâmica, relacionamos as principais contribuições teóricas dos autores da chamada "análise do sistema-mundo", inspirados pela tradição inaugurada por Braudel.

O princípio metodológico que embasa essa perspectiva é o princípio da totalidade, em que o concreto deve ser compreendido como uma unidade de suas múltiplas determinações. ${ }^{10}$ As diversas dimensões do concreto devem ser compreendidas de forma interligada e em constante transformação. É necessário incorporar e explicar, de forma conjunta, todos os processos determinantes da sociedade capitalista. A dimensão do espaço global e do tempo são elementos imprescindíveis para a análise marxiana baseada nesse princípio, seja porque constituem elementos exclusivos que apresentam implicações específicas para o processo capitalista, seja porque as dimensões do espaço e do tempo são o próprio locus do devir histórico. Devido a esse princípio, é inconcebível uma análise marxiana que não leve em consideração as transformações históricas da sociedade. As próprias categorias estão em constante transformação, e a dimensão do espaço e do tempo é crucial para entendê-las.

A análise do sistema-mundo busca compreender a dinâmica capitalista em seu nível "macro", ou seja, pelas relações que se estabelecem entre as nações que se

10 De acordo com Lukács (1968, p. 27, tradução nossa), "Não é a primazia dos motivos econômicos na explicação histórica que constitui a diferença decisiva entre o marxismo e o pensamento burguês, mas o ponto de vista da totalidade.”. 
inserem no modo de produção capitalista. Wallerstein estabelece quatro princípios derivados do princípio da totalidade que são necessários para a análise do sistemamundo: globalidade, historicidade, unidisciplinaridade e holismo (WALLERSTEIN, 1996).

O primeiro princípio, da globalidade, refere-se ao fato de que a unidade básica de análise é o sistema global e não uma sociedade ou nação específica. ${ }^{11}$ Não há uma compreensão atomística de um sistema formado por diversas unidades, sendo o todo apenas o somatório dessas partes, mas sim a compreensão de que há um todo que apresenta uma dinâmica própria, dotado de partes que são, ao mesmo tempo, constituintes e constituídas por esse todo. Não se pode entender uma parte do todo separadamente: apenas na dinâmica do todo é que se revela a natureza da parte. $\mathrm{O}$ segundo princípio, da historicidade, refere-se ao fato de que a história, em um processo sistêmico, também não pode ser compreendida apenas como a história das partes, mas deve ser entendida também como a história do sistema em geral. $\mathrm{O}$ terceiro princípio, da unidisciplinaridade, refere-se ao fato de que todo processo social não é apenas um processo econômico, um processo político ou um processo histórico, mas está, em maior ou menor grau, envolvido nessas múltiplas dimensões. Os processos que emergem historicamente não apresentam, portanto, lógicas segmentadas, mas inter-relacionadas. O holismo, último princípio estabelecido por Wallerstein, deriva logicamente dos anteriores e estabelece que a análise sociológica deve ser compreendida em suas múltiplas dimensões, e não da forma segmentada como são estabelecidas as ciências sociais atualmente.

Portanto, o princípio da totalidade e da multiplicidade de determinações é o que embasa a abordagem do sistema-mundo. Contudo cabe a ressalva de que esse princípio não deve ser compreendido como "determinismo estrutural", em que a lógica e a dinâmica das partes que constituem o sistema são definidas completamente pelos movimentos do todo, da estrutura e de sua dinâmica. $\mathrm{Na}$ verdade, as partes constitutivas do todo apresentam autonomia própria e sua interação é essencial para entender os resultados históricos concretos para além da própria dinâmica do sistema. O chamado "determinismo estrutural” é, nesses termos, um equívoco teórico da mesma forma que o "individualismo metodológico", pois este é incapaz de perceber os efeitos sistêmicos, as propriedades que emergem apenas na interação das partes dentro do sistema, enquanto aquele nega a importância da ação consciente de indivíduos ou de grupos/ classes na transformação social. Dessa forma, ao mesmo tempo em que o todo apresenta sua própria lógica, as partes constitutivas do todo também apresentam dinâmica própria, porém sempre restritas à estrutura em que se inserem.

11 Para críticas ao chamado nacionalismo-metodológico, ver Medeiros (2010). 
Braudel (1987, Cap. 3), buscando interpretar o "tempo do mundo", apresenta o conceito de economia-mundo, que se baseia no princípio da totalidade. Uma economia-mundo pode ser definida como a economia de uma porção do planeta em espaço geográfico limitado, na medida em que essa porção forma um todo econômico. Esse conceito difere do de "economia mundial", que seria simplesmente o agregado da economia de todas as regiões do globo (BRAUDEL, 1987, p.68). O conceito de Braudel é análogo ao de sistema-mundo de Immanuel Wallerstein, que pode ser definido como "uma unidade em que há uma única divisão do trabalho e múltiplos sistemas culturais" (WALLERSTEIN, 2000). ${ }^{12}$ Braudel afirma que a sua interpretação e a de Wallerstein são análogas. ${ }^{13}$

Uma economia-mundo apresenta características específicas que derivam do fato de que as suas partes formam um sistema, indo além do mero agregado dessas partes: ela ocupa um espaço geográfico dado, restrito, cujos limites variam com certa lentidão após longos intervalos e rupturas; apresenta um polo, um centro, que atua como um núcleo econômico do sistema e que é representado normalmente por uma cidade dominante ou por um mercado nacional dominante; ela se reparte em zonas sucessivas, que apresentam uma relação de hierarquia e de dominação, e estão normalmente dispostas como um núcleo que fica próximo ao centro, com zonas intermediárias próximas a esse núcleo e zonas periféricas nas margens da economia-mundo. Essas propriedades emergem apenas quando se estabelece um processo econômico sistêmico em determinada região. Veremos, a seguir, a descrição das características de uma economia-mundo levantadas por

12 É necessário ressaltar que, em Wallerstein, o conceito de "economia-mundo" descreve exclusivamente sistemas-mundo em que não há um sistema político comum. Quando há um sistema político comum, Wallerstein os designa como "impérios-mundo" (WALLERSTEIN, 2000).

13 Apesar de apontar a similitude das duas interpretações, Braudel ressalta que Wallerstein entende apenas como sistema-mundo a economia-mundo europeia: "Pouco importa que eu não esteja sempre de acordo com o autor sobre tal ou tal ponto, até mesmo sobre uma ou duas linhas gerais. Os nossos pontos de vista, quanto ao essencial, são idênticos, ainda que, para Immanuel Wallerstein, não haja outra economia-mundo além da Europa, fundada a partir do século XVI, somente, enquanto que para mim, muito antes de ter sido conhecido pelo homem da Europa na sua totalidade, desde a Idade Média e mesmo desde a Antiguidade, o mundo já estava dividido em zonas econômicas mais ou menos centralizadas, mais ou menos coerentes, ou seja, em várias economias-mundo que coexistem" (BRAUDEL, 1987, p.70). No entanto, Wallerstein, ao descrever a evolução do sistema-mundo capitalista, reconhece a existência de outros sistemas-mundo: "Ela [a economia-mundo capitalista] rapidamente atingiu um ponto de equilíbrio em suas relações com outros sistemas-mundo: os impérios-mundo Russo e Otomano, a proto-economia-mundo do Oceano Indiano" (WALLERSTEIN, 2000, p. 93). A interpretação passa a considerar que há um único sistema-mundo apenas com base na expansão do capitalismo industrial, cujo centro é a Inglaterra: “A expansão geográfica da economia-mundo europeia significou a eliminação de outros sistemas-mundo assim como a absorção dos mini-sistemas remanescentes" (WALLERSTEIN, 2000, p. 94). 
Braudel e suas implicações para a dinâmica do sistema-mundo capitalista a partir da teorização de Arrighi e Wallerstein.

Em primeiro lugar, é necessário ressaltar a questão da limitação geográfica do sistema-mundo. Pelas definições de Braudel e de Wallerstein, entende-se como economia-mundo não só a economia-mundo europeia, mas também as existentes na Ásia, que concentram outras economias-mundo que se mantêm consolidadas até o final do século XVIII, como a China, o Japão, a Índia-Insulínda e o Islã (BRAUDEL, 1987, p. 78). Nesses termos, Braudel (1987, p. 71) afirma:

Assim é possível colocar, no mapa e na história do mundo, um decalque transparente onde, para cada época dada, um traço a lápis delimita grosso modo as várias economiasmundo. Como essas economias mudam lentamente, temos todo o tempo necessário para estudá-las, vê-las viver e avaliar-lhes o peso. Lentas em deformar-se, elas assinalam uma história profunda do mundo.

Com a emergência das relações mercantis de longa distância na economiamundo europeia, juntamente com a gradual consolidação do modo de produção capitalista, essa economia-mundo passou a expandir, entre processos lentos e rupturas, as suas limitações geográficas. Wallerstein (2000, p. 93) afirma que a "crise do feudalismo" existente na emergência da economia-mundo europeia impôs como solução a expansão geográfica da divisão do trabalho. Assim, há uma primeira expansão geográfica da economia-mundo europeia.

Posteriormente, com a passagem do centro da economia-mundo de Amsterdam para a Inglaterra e com a ascensão do modo de produção especificamente capitalista, dominado pela maquinaria e pela grande indústria, a expansão gradual das fronteiras da economia-mundo europeia levou a uma economia mundial como sistema-mundo único. Essa expansão da economia-mundo europeia está relacionada ao processo de acumulação de capital existente no modo de produção capitalista. Wallerstein (2000, p. 94) sustenta que esse processo de expansão geográfica, eliminando as demais economias-mundo, foi resultado das transformações tecnológicas, principalmente as relacionadas às melhorias nos armamentos militares e nas embarcações utilizadas nas navegações de longa distância, que fizeram com que o comércio se tornasse mais viável. Além disso, a expansão capitalista europeia demandava matérias-primas em quantidade e qualidade que não poderiam ser supridas no espaço geográfico anterior. Em outras palavras, é o desenvolvimento das forças produtivas e as necessidades de acumulação que expandem geograficamente o sistema-mundo. ${ }^{14}$ Essas transformações

14 Sobre o aspecto da expansão geográfica do capitalismo, é necessário observar as contribuições de Milton Santos (1997) e das chamadas "teorias do imperialismo" presentes em Lenin (2012) e em Rosa Luxemburgo (1976), e as abordagens dependentistas resumidas em Palma (1978). Milton Santos descreve a permanente tensão entre o espaço local e o espaço global, em que o tempo e o espaço local 
no espaço geográfico do capitalismo ocorrem a cada novo ciclo sistêmico de acumulação. No entanto, não se pode compreender completamente esse processo de forma dissociada das demais características sistêmicas do sistema-mundo.

A ampliação dos espaços pode ser explicada pela dinâmica dos ciclos sistêmicos de acumulação, conceito apresentado por Giovanni Arrighi para compreender os ciclos de longa duração no sistema-mundo e, principalmente, o processo de sucessões de hegemonia (ARRIGHI, 1996). Ao término de cada novo ciclo, o espaço do sistema-mundo se amplia e há um novo centro, um novo núcleo, uma nova "capital econômica", conforme coloca Braudel (1987, p. 69). O autor denomina como "descentragem" e "recentragem" os processos históricos de mudança do centro do sistema-mundo:

Toda vez que ocorre uma descentragem, opera-se uma recentragem, como se uma economia-mundo não pudesse viver sem um centro de gravidade, sem um polo. Mas essas descentragens e recentragens são raras, o que as reveste ainda de mais importância. No caso da Europa e das zonas que ela anexa, operou-se uma centragem na década de 1380, em benefício de Veneza. Por volta de 1500, houve um salto brusco e gigantesco de Veneza para Antuérpia, depois, em 1550-1560 um retorno ao Mediterrâneo, mas desta vez em favor de Gênova; enfim, por volta de 1590-1610, uma transferência para Amsterdam, onde o centro econômico da zona europeia se estabilizará por quase dois séculos. Entre $1790 \mathrm{e}$ 1815 deslocar-se-á para Londres. Em 1929, atravessa o Atlântico e situa-se em Nova Iorque (BRAUDEL, 1987, p.72).

Pode-se afirmar que há quatro grandes ciclos sistêmicos de acumulação: o ciclo genovês (Veneza/Gênova), o ciclo holandês, o ciclo britânico e o ciclo americano. Cada um desses ciclos apresenta um núcleo associado, um polo de acumulação de capital, um epicentro. Nos dois primeiros, esses núcleos são cidadesEstados, enquanto, nos dois últimos, o mercado que constitui o centro deixa de ser apenas o mercado urbano, da cidade, e passa a ser o mercado nacional (Inglaterra e Estados Unidos).

Assinale-se que, até por volta de 1750, esses centros dominadores foram sempre cidades, ou cidades-Estados. Porquanto se pode muito bem dizer que Amsterdam, que domina o mundo da economia ainda em meados do século XVIII, foi a última das cidades-Estados,

perdem a dinâmica própria com o sistema internacional, passando a serem unidades do movimento global, com a expansão da divisão do trabalho e a homogeneização das técnicas. Os espaços globais são pontuais e descontínuos, como pontos ligados ao sistema global. Por outro lado, as teorias do imperialismo ressaltam que o excesso de capital acumulado seria o elemento que gera a expansão geográfica do capitalismo, com exportação de capital para as regiões periféricas em Lenin ou a busca por novos mercados a partir de sociedades pré-capitalistas, como em Rosa Luxemburgo. 
das polis da história. Por trás dela, as Províncias Unidas exercem apenas uma sombra de governo. Amsterdam reina sozinha, farol luminoso que se vê do mundo inteiro, desde o mar das Antilhas até às costas do Japão. Pelo contrário, em meados do Século das Luzes começa uma era diferente. Londres, a nova soberana, não é uma cidade-Estado, é a capital das ilhas britânicas que lhe fornecem a força irresistível de um mercado nacional. [...] Portanto, duas fases: as criações e dominações urbanas; as criações e dominações "nacionais".

Tanto Braudel quanto Arrighi ressaltam o fato de que todas essas transformações do sistema-mundo ocorrem em processos de fortes crises econômicas prolongadas, gerando lutas e choques que levam à mudança do centro do sistemamundo. Braudel (1987, p. 73) afirma que "é através dessas crises que se deve, sem dúvida, abordar o difícil estudo desses mecanismos de conjunto por meio dos quais a história geral se reconstitui”. Os ciclos sistêmicos de acumulação descritos por Arrighi nada mais são do que processos de acumulação de capital cuja própria dinâmica cria as condições para a crise. Conforme afirma Marx (1998), "a verdadeira barreira à produção capitalista é o próprio capital”. Arrighi descreve a dinâmica dos ciclos como sendo formados por uma primeira etapa de expansão da riqueza material, com o aumento absoluto da produção e do comércio de mercadorias, e uma segunda etapa de expansão financeira, em que cresce o comércio de moedas e o que é chamado por Marx (1998) de acumulação de capital-dinheiro, incluindo valores fictícios.

A passagem de um ciclo de acumulação para o outro é marcada por dois momentos de crise. O primeiro é a chamada "crise sinalizadora", e o segundo, a "crise terminal” (ARRIGHI, 1996, p. 220). De acordo com Arrighi, a crise sinalizadora marca a mudança entre as etapas do ciclo sistêmico de acumulação, passando da etapa de expansão material para a de expansão financeira. A partir desse momento, o excedente do ciclo em decadência passa a financiar o novo ciclo de acumulação de capital, que surge paralelamente a esse. A crise terminal marca o fim do ciclo sistêmico de acumulação de capital, quando já deve existir esse novo ciclo em expansão, provavelmente com um novo polo geográfico de acumulação.

Os ciclos sistêmicos de acumulação são análogos à ideia de séculos longos de Braudel, em que o tempo de cada ciclo tende a diminuir, sendo cada vez mais curtos, e o espaço tende a aumentar com a incorporação de território. Assim, entende-se o que leva à expansão territorial do sistema-mundo de forma gradual e marcada por rupturas. Cabe ressaltar ainda que há diferentes regimes de acumulação de capital em cada um dos ciclos sistêmicos de acumulação, assim como em diferentes classes de capitalistas que dominam cada período.

Por se tratar de um período incipiente do modo de produção capitalista, em que o pequeno proletariado urbano é assalariado, tem apenas subsunção formal ao capital, enquanto a maior parte do processo de acumulação é realizado pelas formas pré- 
capitalistas de capital, o capital comercial e o capital usurário. Essa fase pode ser entendida como a fase comercial, em que o capital comercial ainda apresenta maior representação que o capital industrial, produtor de mais-valor. Segundo Wallerstein (2000), essa fase é a do "capitalismo agrícola", em que predomina, na economiamundo europeia, o comércio de produtos agrícolas visando ao lucro, com uma divisão do trabalho marcada pela especialização de determinadas regiões na produção de certos produtos agropecuários. Por outro lado, com a ascensão do capital industrial e com o seu desenvolvimento gradual, de acordo com Marx, passa a ser menor o peso relativo do capital comercial, que passa a cumprir as funções de circulação do capital industrial. ${ }^{15} \mathrm{Com}$ esse processo, a dinâmica da acumulação deixa de ser baseada no lucro do comércio desigual nas longas distâncias ou na usura sobre produtores camponeses pré-capitalistas e passa a ser um processo verdadeiramente capitalista, em que o mais-valor é produzido pelo capital industrial produtor de mercadorias e realizado e apropriado no processo de circulação. Wallerstein afirma que essa é a fase industrial da evolução do sistema-mundo. Os ciclos sistêmicos de acumulação, descritos dessa forma, podem ser observados na Figura 2.

Figura 2 - Ciclos sistêmicos de acumulação de Arrighi

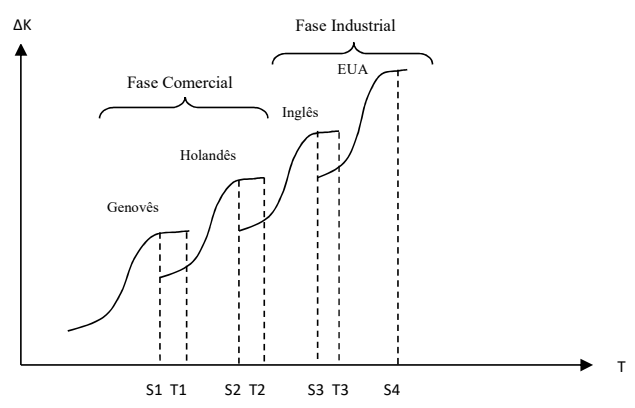

Uma crítica comum à abordagem de Arrighi está relacionada ao seu caráter determinista, em que haveria uma regra para a queda e o surgimento de cada nova hegemonia. ${ }^{16}$ Fiori (2008), por exemplo, afirma que a crise dos anos 70, interpretada por Arrighi como a crise sinalizadora do fim do ciclo hegemônico americano, não representa necessariamente a queda do país como centro hegemônico global. De fato,

15 Cabe lembrar que o capital industrial aqui referido é o capital que produz mais-valor, assumindo a forma capital-dinheiro, capital-mercadoria e capital-produtivo. Assim, não se trata do setor industrial especificamente, mas também da agricultura e dos serviços.

16 Arrighi discute em Adam Smith em Pequim (2008) a mudança do centro hegemônico do sistemamundo dos Estados Unidos para a China, processo que decorreria da crise do ciclo sistêmico de acumulação americano. 
Fiori aceita que, nesse período, há uma queda do poder relativo americano. Porém afirma que os elementos que sustentam seu poder hegemônico não foram abalados. Por outro lado, em relação às sucessões hegemônicas, Braudel sustenta o seguinte:

Tudo isso [o processo de recentragem], evidentemente, [ocorre] sem regularidade matemática: uma crise insistente é uma provação que os fortes superam e vencem, os fracos lhe sucumbem. Portanto, o centro não racha a cada golpe.[...] Vivemos hoje, há alguns anos, uma crise mundial que se anuncia forte e duradoura. Se Nova Iorque sucumbir à provocação - no que realmente não creio - o mundo deve encontrar ou inventar um novo centro; se os Estados Unidos resistem, como tudo nos deixa prever, poderão sair mais fortes da experiência, pois que as outras economias correm o risco de sofrer muito mais do que os Estados Unidos em decorrência da conjuntura hostil que atravessamos (BRAUDEL, 1987, p.73).

Portanto os processos de descentragem e recentragem, que têm suas raízes nos períodos de crises econômicas, são essenciais para que se possa entender a dinâmica do sistema-mundo. Com o esgotamento de um padrão de acumulação e o surgimento de um novo padrão, o núcleo do sistema se altera, de forma a possibilitar a emergência do novo ciclo de acumulação em uma região geográfica distinta. Braudel afirma ser possível que, por um certo período de tempo, existam dois centros simultâneos em uma economia-mundo. ${ }^{17}$ Entretanto esse processo tende a ser transitório, pois Braudel afirma que um desses dois centros acaba sempre por ser eliminado.

Uma última característica do sistema-mundo, relacionada ao fato de que sempre há um centro no processo global de acumulação, é o fato de que o sistema se divide em regiões hierarquizadas, zonas concêntricas que são determinantes para a dinâmica econômica e política de cada Estado-nação de acordo com sua posição estrutural. Essas zonas concêntricas são "cada vez menos favorecidas à medida que se distanciam do seu polo triunfante” (BRAUDEL, 1987, p. 75). Podemos definir, então, três posições estruturais no sistema-mundo que apresentam características distintas: a primeira é o centro.

O esplendor, a riqueza, a alegria de viver, reúnem-se no centro da economia-mundo, em seu núcleo. É aí que o sol faz brilhar as cores mais vivas, é aí que se manifestam os preços altos, os salários altos, os bancos, as mercadorias "reais", as indústrias lucrativas, as agriculturas capitalistas; é aí que se situam o ponto de partida e o ponto de chegada dos extensos tráficos, o afluxo de metais preciosos, das moedas fortes, dos títulos de crédito. Toda uma modernidade econômica em avanço aí se aloja: o viajante assinala-o quando vê

17 "Roma e Alexandria ao tempo de Augusto, Antônio e Cleópatra; Veneza e Gênova ao tempo da guerra de Chioggia (1378-1381); Londres e Amsterdam no século XVIII, antes da eliminação definitiva da Holanda.” (BRAUDEL, 1987, p. 69). 
Veneza no século XV, ou Amsterdam no século XVII, ou Londres no Século XVIII, ou Nova Iorque hoje. As técnicas de ponta também aí estão, habitualmente, e a ciência fundamental acompanha-as, está com elas. As "liberdades" aí se alojam, não sendo inteiramente mitos nem inteiramente realidades. (BRAUDEL, 1987, p. 75)

O centro do sistema-mundo sustenta sua posição estrutural por se apropriar do excedente produzido nas demais áreas geográficas do sistema. Assim, "o capitalismo não envolve apenas apropriação de mais-valor pelo dono do trabalhador, mas também apropriação de excedente de toda economia-mundo pelas áreas centrais" (WALLERSTEIN, 2000, p. 86). Existe uma relação de dominação do centro em relação às demais regiões e o processo global de acumulação, representado pelos ciclos sistêmicos de acumulação, é possibilitado justamente por essa posição hierárquica.

A segunda posição no sistema-mundo é a de países intermediários, que são vizinhos, concorrentes e êmulos do centro:

Aí, poucos camponeses livres, poucos homens livres, trocas imperfeitas, organizações bancárias e financeiras incompletas, mantidas frequentemente do exterior, indústrias relativamente tradicionais. Por muito bela que a França pareça ser no século XVIII, o seu nível de vida não se compara com o da Inglaterra. John Bull, "superalimentado”, comedor de carne, calça sapatos; e o francês Jacques Bonhomme, franzino, comedor de pão, macilento, envelhecido prematuramente, calça tamancos. (BRAUDEL, 1987, p. 76)

Essa posição intermediária é considerada por Wallerstein (2000) a semiperiferia do sistema-mundo, e é essencial para entender a dinâmica política global. Esses países tornam o sistema politicamente mais estável devido ao fato de que são, ao mesmo tempo, exploradores e explorados. Parte do excedente produzido nesses estratos médios é apropriado no centro, porém a semiperiferia também se apropria de parte do excedente produzido pela última posição estrutural do sistema-mundo.

Finalmente, muito amplas, as margens que, na divisão de trabalho que caracteriza a economia-mundo, são mais subordinadas e dependentes do que participantes. Nessas zonas periféricas, a vida dos homens evoca frequentemente o Purgatório, ou mesmo o Inferno. E a razão suficiente disso é, realmente, a sua situação geográfica. (BRAUDEL, 1987, p. 69-70)

A periferia apresenta uma dinâmica capitalista impulsionada principalmente da dinâmica proveniente da acumulação do centro. Os impulsos dinâmicos ao longo de diversos ciclos sistêmicos de acumulação levaram à formação de sociedades escravagistas na América Latina e de uma segunda servidão no leste europeu, principalmente para suprir as necessidades de acumulação advindas do centro. A subordinação da periferia é algo claro no sistema-mundo: há um 
processo de apropriação do excedente produzido nessas zonas que ocorre em regiões centrais. Segundo afirma Braudel, "o capitalismo vive dessa sobreposição regular: as zonas externas alimentam as zonas medianas e, sobretudo, as centrais" (BRAUDEL, 1987, p. 77).

As posições hierárquicas de cada nação no sistema-mundo apresentam não só implicações econômicas diretas, como essa relação de expropriação da periferia, mas também relações políticas conflituosas. O sistema interestatal formado pelos EstadosNação do sistema-mundo é hierárquico de acordo com as posições estruturais ocupadas por cada uma dessas nações. De acordo com Wallerstein (2000, p. 89):

Não se pode razoavelmente explicar a força das várias máquinas estatais em momentos específicos da história do sistema-mundo moderno primordialmente em termos de uma linha de argumentação cultural-genética, mas sim em termos do papel estrutural que um país ocupa na economia-mundo naquele momento do tempo.

Assim, o papel que cada país ocupa no sistema-mundo não é algo dado, imutável, mas sim um achado de sua história, no sentido de que depende de “acidentes” históricos ou geográficos que, com as forças dinâmicas da acumulação capitalista, se institucionalizam e se tornam impossíveis de superar no curto prazo. Porém as disputas pela hegemonia permanecem constantes, sendo uma tática comum de Estados-Nação, juntamente com a burguesia, a criação de barreiras nacionais ("semirretirada mercantilista") para fortalecer seu poder econômico e disputar novas posições estruturais no sistema-mundo.

Wallerstein afirma que, apesar de contraditório, o sistema-mundo apresenta mecanismos que garantem relativa estabilidade política. Em primeiro lugar, há uma tendência de concentração de poder militar nos Estados do centro, seja pelo desenvolvimento tecnológico, seja pela exploração da periferia que enfraquece a sua máquina estatal. $\mathrm{O}$ Estado na periferia é mais fraco, segundo Wallerstein, devido à menor propensão da existência de uma coalizão de classes para disputar o poder hegemônico e à coerção ocasionada por intervenções externas, seja em termos bélicos ou através da diplomacia de Estados do centro. Em segundo lugar, a existência de um estrato médio, a semiperiferia, garante que não haja uma oposição unificada ao centro, estabilizando politicamente o sistema e oscilando entre alianças e disputas com o poder central.

\section{Conclusão}

Nosso objetivo com este trabalho foi, em primeiro lugar, partindo das análises teóricas de Braudel e Marx sobre a formação do capitalismo na Europa, buscar uma 
interpretação teórica coerente para a formação do sistema-mundo capitalista e, em segundo lugar, partindo das análises de Braudel, Arrighi e Wallerstein, sustentar uma interpretação teórica coerente (e consistente com a interpretação anterior) para a dinâmica desse sistema-mundo. Essas são interpretações preliminares, pois não esgotam o tema em sua elevada complexidade.

A análise de Braudel sobre a emergência do capitalismo na Europa ressalta a importância do comércio de longa distância e do comércio de dinheiro com atravessadores que manipulam os mercados obtendo lucros extraordinários. Essa burguesia mercantil, que emerge através desse processo, se relaciona com o Estado de forma a manter posições hierárquicas privilegiadas, assegurando suas rotas de comércio. A partir de Marx, interpretamos essa análise como um processo de acumulação baseado nas formas pré-capitalistas de capital, o capital comercial e usurário. Além disso, Marx demonstra que o processo de acumulação capitalista, o qual é necessário para explicar os ciclos sistêmicos de acumulação do sistemamundo, depende da separação entre força de trabalho e meios de produção. Desse modo, descrevemos a tradicional abordagem de Marx sobre o processo de acumulação primitiva.

Por fim, procuramos, resumidamente, expor e relacionar as perspectivas de Braudel, Arrighi e Wallerstein na explicação da dinâmica do sistema-mundo capitalista, apontando a necessidade de se ter como objeto de análise básico a economia-mundo em sua totalidade. Primeiramente, ressaltamos as transformações espaciais que ocorrem de forma secular no sistema-mundo, com um processo de ampliação do espaço de acumulação. Em segundo lugar, descrevemos os processos cíclicos ocasionados pelas crises de acumulação que levam à descentragem e à recentragem do sistema-mundo e a sucessões de poderes hegemônicos. Por fim, descrevemos as posições estruturais existentes nesse sistema - centro, semiperiferia e periferia -, demonstrando o caráter exploratório derivado da própria dinâmica capitalista e que apresenta efeito primordial sobre as regiões e os Estados nacionais que nelas se encontram.

A análise do sistema-mundo é um marco teórico e analítico rico e consistente para compreender e interpretar as relações internacionais. Partindo da perspectiva apresentada, derivam-se diversas outras questões de natureza socioeconômica e geopolítica, em que o processo de acumulação, os ciclos sistêmicos e as disputas hegemônicas são inseparáveis entre si.

\section{Referências}

ARRIGHI, Giovanni. O Longo Século XX: dinheiro, poder e as origens do nosso tempo. Rio de Janeiro: Contraponto; São Paulo: Editora UNESP, 1996. 
ARRIGHI, Giovanni. Adam Smith em Pequim. Boitempo, 2008.

BRAUDEL, Fernand. A Dinâmica do Capitalismo. Rio de Janeiro: Rocco, 1987.

FARIA, Luiz Augusto Estrella. Olhares sobre o capitalismo: estruturas, instituições e indivíduos na economia política. Ensaios FEE, Porto Alegre, v. 28, n. 2, p. 325-352, out. 2007.

FERNANDES, Florestan. A Revolução Burguesa no Brasil: ensaio de interpretação sociológica. $5^{\text {a }}$ Ed. São Paulo: Globo, 2005. 504p.

FIORI, José L. O sistema interestatal capitalista no início do século XXI. In: FIORI, José L., MEDEIROS, Carlos A. e SERRANO, Franklin. O mito do colapso do poder americano. Rio de Janeiro: Record. 2008.

LENIN, V. I. Imperialismo, estágio superior do capitalismo. $1^{\text {a }}$ Ed. São Paulo: Expressão Popular. 2012.

LUKÁCS, George. The Marxism of Rosa Luxemburg. In: LUKÁCS, George. History and Class Consciousness: Studies in Marxist Dialetics. Londres: Merlin Press, 1968.

LUXEMBURGO, Rosa. A acumulação de capital. Rio de Janeiro: Zahar, 1976.

MARX, Karl. O Capital: crítica da economia política. Livro I - O processo de produção do capital, Vol. 1. 30 Ed. Rio de Janeiro: Civilização Brasileira, 2008.

MARX, Karl. O Capital: crítica da economia política. Livro I - O processo de produção do capital, Vol. 2. 16 ${ }^{\text {a }}$ Ed. Rio de Janeiro: Civilização Brasileira, 1998.

MARX, Karl. O Capital: crítica da economia política. Livro III - O processo global de produção capitalista, Vol. 2. $2^{\text {a }}$ Ed. São Paulo: Nova Cultural, 1998. (Os Economistas) MEDEIROS, Carlos Aguiar de. Instituições e desenvolvimento econômico: uma nota crítica ao chamado "nacionalismo-metodológico". Economia e Sociedade, Campinas, v. 19, n. 3 (40), dez. 2010. DOI: https://doi.org/10.1590/S0104-06182010000300009

PALMA, Gabriel. Dependency: a formal theory of underdevelopment or a methodology for the analysis of concrete situations of underdevelopment? World Development, Vol. 6. Londres, 1978. DOI: https://doi.org/10.1016/0305-750X(78)90051-7 
PRADO JR., Caio. A Revolução Brasileira: Perspectivas em 1977. São Paulo: Brasiliense, 2004. 267p.

SANTOS, Milton. Técnica, espaço e tempo: globalização e meio técnico-científico informacional. São Paulo: Hucitec. 1997.

WALLERSTEIN, Immanuel. The Rise and Future of World-Systems Analysis. $91^{\text {st }}$ Annual Meeting of the American Sociological Association. Nova Iorque, 1996.

WALLERSTEIN, Immanuel. The essential Wallerstein. Nova Iorque: The New Press, 2000.

Recebido em 08.01.18

Aprovado em 28.03.19 